\title{
Critical evaluation of Theonomist eschatology
}

Author:

Morne Diedericks ${ }^{1}$ (D

\section{Affiliation:}

${ }^{1}$ Department of Education and Biblical Studies, Faculty of Education, Akademie Reformatoriese Opleiding en Studies, Pretoria,

South Africa

\section{Corresponding author:}

Morne Diedericks,

morne.diedericks@aros.ac.za

Dates:

Received: 26 Mar. 2021

Accepted: 25 June 2021

Published: 01 Sept. 2021

How to cite this article:

Diedericks, M., 2021, 'Critical

evaluation of Theonomist

eschatology', In die Skriflig

55(1), a2753. https://doi.

org/10.4102/ids.v55i1.2753

\section{Copyright:}

(C) 2021. The Authors.

Licensee: AOSIS. This work

is licensed under the

Creative Commons

Attribution License.
Although the extreme form of Theonomism has only affected a small number of Reformed members in South Africa, it seems that Theonomist Postmillennialism has a greater underlying influence in the Reformed Churches in South Africa. General churchgoers in the Reformed Churches of South Africa generally confuse the Regulatory Principle with Theonomism and are uninformed about precisely what Theonomism is. Furthermore, signs of Theonomism as it developed in the USA are also visible in South Africa. Yet, there is great ignorance about the exact effect that Theonomism has on Reformed congregations in South Africa, especially regarding the eschatological views held by individual congregations.

Contribution: The thesis of this article is that the Theonomistic eschatology influences congregations' mission and causes a shift from a focus on proclaiming the gospel to the nations, in being a church that seeks to restructure the institutions of political societies.

Keywords: Amillennialism; eschatology; postmillennialism; reconstructionism; regulatory principle; theonomism.

\section{Introduction}

Theonomism originally developed in the United States of America (USA). Theonomism, as it developed in the USA through the writings of Rousas J. Rushdoony, Gary North, Greg L. Bahnsen, David Chilton, Gary DeMar, Kenneth L. Gentry, and Ray Sutton, is described by Kline (1977:619) as the Chalcedon movement. Ingersoll (2015) says:

If Rushdoony is the architect of the theological and philosophical system, and Chilton is the general contractor in charge of developing and popularizing postmillennialism, Gary North is the site foreman with the on-the-ground plans for taking dominion. (p. 31)

The influence of Theonomism should not be underestimated. Frame (1976:195) especially highlights the valuable contribution of the work in his discussion of Rushdoony's work, The institutes of biblical law. McVicar (2015) highlights the influence of the Theonomistic Reconstructionism, in which he explains why they form the basic framework for right-wing politics in America.

Gaffin (1990:197) shows that the Theonomism of the Chalcedon movement also spilt over to South Africa. General churchgoers in the Reformed churches sometimes call the movement, out of ignorance, the 'Regulatory Principle' (McCrorie 2006). This group is characterised by their ecclesiastical devotion, their strong opinions about the family, large families and their fiery devotion to home-schooling. The group is also known for its activism on social media, anti-state attitude, active involvement in community organisations that oppose the state and has a negative attitude towards the current state of the church (Ingersoll 2015:63). The group is also identified by their secession from existing congregations and establishment of new congregations. Some of the criticism against the group is about their strict patriarchal attitude, strong nationalism, characteristic racism, and a view that the woman is seen as a material possession (Burack 2017:4).

Although Theonomism is a declining movement in the USA, Ingersoll (2015:6) points out that Theonomism has had a lasting effect on numerous aspects of church and state, and especially on the eschatological views held by individual congregations. A congregation's eschatological view determines the way it sees its task and role today (Gaffin 2006:30). A congregation's eschatological view therefore influences its agenda and focus. The following example attempts to illustrate this. One Sunday morning in a worship service, the pastor delivered a sermon that dealt with the political decay in South Africa, the crisis with Eskom (the main electricity provider in South Africa) and why the congregation should be more politically active. Little did the congregation know that the sermon was preparing for what would take place after the worship service. After the worship service, a community organisation gave a presentation on why the congregation was now a member of the organisation, and how the congregation could recruit members for the 
organisation. For every member recruited the congregation receives money from the community organisation. This left the author with some questions. What should be the task and focus of the church? Is it the task of the congregation to recruit members for community organisations? What is the underlying influence that contributed to the church council's decision? By conducting a literature study, this article provides an overview of Theonomism, Theonomistic eschatology and a critical evaluation of the Theonomistic eschatology.

\section{Overview of Theonomism}

Confusion about what Theonomism is, and the different groups that classify themselves as Theonomist, necessitates that Theonomism must first be described. Theonomistic views are sometimes incorrectly classified as the 'Regulatory Principle' (McCrorie 2006). The correct understanding of the Regulatory Principle is concerned with implementing the second commandment by regulating the worship service. ${ }^{1}$ The Regulatory Principle only regulates the worship service and requires three things: Whatever is commanded by Scripture is required, whatever is forbidden by Scripture is prohibited, and whatever is not commanded in Scripture is forbidden (Pipa 2020:59). Any Reformed member would agree that worship should be regulated by the Word of God. The Regulatory Principle, however, entails that Scripture determines what should and what should not be done during worship. Should the worship service not be regulated, each congregation could decide for itself how they would organise the worship service according to their own preferences. This would include candles during the worship service, bands, videos, movies, performances, and so forth, without any regulation. However, confusing the Regulatory Principle with Theonomism causes great misperception. The confusion comes in when informed Theonomists present the so-called 'Regulatory Principle' as a valuable principle for regulating the worship service, and just because the Reformed Church member is wary of the stigma surrounding the false understanding of the Regulatory Principle, they deny the Regulatory Principle. Theonomism should therefore not be confused with the Regulatory Principle. The Reformed Confession endorses the Regulatory Principle, but not Theonomism.

Theonomism, as a word, is derived from two words, namely Theos (God) and nomos (law). The uniqueness of Theonomism has to do with the specific view of God's law. The law of God, as revealed in the Old Testament, is divided into three parts, namely the moral law (Decalogue), judicial law and the ceremonial laws. Beale (2011:872) explains that the division of the laws in this way, is merely a practical categorisation and that the division is more complex. Wenham (2006:354) offers a more nuanced division of the law, but also includes the three aspects, namely Moral Law, Judicial Law and Ceremonial Law. The uniqueness of Theonomism does not image of God in any way, nor to worship him in any other mann
commanded in his Word' (Heidelberg Catechism, Lord's Day 35). lie in the fact that its proponents are positive about God's law, because the church has always, over the centuries, been committed to the Nomos (Law) of Theos (God), in the sense that it is God's law and is regarded as the revealed will of God. What distinguishes Theonomism from the traditional view of the Church, is that Theonomism holds to the continuity of the judicial law, as given to Old Testament Israel, except for the judicial laws that were brought to fulfilment in the New Testament (McVicar 2015:5). Theonomists acknowledge that the ceremonial laws were fulfilled in Jesus Christ, and therefore no longer apply today. Theonomism is thus characterised by its specific view of the Old Testament judicial laws and the validity of the judicial laws today (Bahnsen 2002:207-214).

North (1991:81), in Christian reconstruction: What it is, what it isn't, describes Theonomism as having the following five characteristics: ${ }^{2}$

- Redemption - salvation by grace and faith alone - is the only hope of man in this and the coming century.

- The continuing validity and applicability of the entire law of God, including but not limited to the Mosaic judicial laws, is the standard by which individuals, families, churches and civil governments must conduct their affairs.

- A victorious view of the future progress of the kingdom of God, before the return of Christ, is the foundation for building a Christian civilisation.

- Presupposition apologetics, as opposed to proof apologetics, are advocated.

- A decentralised social order, where the civil government is only one legitimate government among many other governments, including family government and ecclesiastical government, is the basis for a free and orderly society.

Theonomism is also known as Reconstructionism, which gives a better expression to the political objective of Theonomism. Reconstructionism refers to the restructuring of society, by putting point two in the above description into practice. Kloosterman (1994) explains:

God's Law (especially, but more than the Mosaic legislation) is valid and binding today. God's Law and obedience to it, become the instrument for the postmillennial victory of Christians in society. (p. 5)

The Reconstructionist nature of Theonomism is the call to build the Kingdom of God on earth through forms of government, or the church applying the judicial law of God in the geopolitical social environment. It is therefore a reconstruction of society, through the application of the judicial law. In building up the Kingdom of God on earth through the application of the Old Testament judicial laws, some Theonomists, such as Bahnsen (1991:82), believe that the Kingdom of God should be expanded by the state or governments application of the judicial laws. Should the state not apply the judicial laws of the Old Testament for the 2.Also see Gentry's (1993:81-82) six characteristics of Theonomism. 
purpose of establishing the Kingdom of God on earth, the state is not really a state, and that state should be opposed and replaced. Should the church not do enough to restructure society, the Theonomists would first rebel against the authority of the church council and point out to the church council the failure of their duties to restructure society (McVicar 2015:5). This is one of the reasons why Theonomists cause so much trouble in the local church, to such an extent that they later establish their own congregations (Hall 2015:11). Theonomism is therefore Reconstructionistic in that it believes that the Church bears the responsibility to restructure society through forms of government, by the implementation and application of the Old Testament judicial law.

Theonomism's view on the Kingdom of God forms part of the encyclopaedia of eschatology. The church's confession about when God will establish his Kingdom on earth, is divided within Eschatology into mainly two categories, namely the Premillennial and Postmillennial eschatological views. In both categories, the Millennium refers specifically to the Millennium or 1000 years in Revelation 20. All millennial views place the Millennium either before, or after the second coming of Jesus Christ. The result is that there are only two main categories of millennial positions: Premillennial - 'pre', because Christ comes before the Millennium, and Postmillennium - 'post', because Christ comes after the Millennium. Premillennialism can be further divided into two subsections, namely Historical Premillennialism and Dispensationalism. Postmillennialism is further divided into Postmillennialism and Amillennialism (Venema 2000:194). Under the classification of eschatology, Theonomism is classified as a specific form of Postmillennialism.

\section{What is Theonomistic eschatology?}

There is a common saying in eschatological circles that not all Postmillennialists are Theonomists, but all Theonomists are Postmillennialists (Kloosterman 1994:3). Although some Theonomists may differ, the author is of the opinion that the eschatology of Theonomism, is a unique form of Postmillennialism. Theonomist eschatology is Postmillennialist, because Theonomism believes that the time in which we now live, is the Millennium (not necessarily a literal 1000 years), and that Jesus Christ's return will take place after (post) this Millennium. However, this is also the view of Amillennialism. What further distinguishes Postmillennialism, however, is the idea of a golden age that will take place in this Millennium. The golden age is characterised by a growth in the numbers of the Church (Kingdom of God) on earth, and a decrease in those of the kingdom of darkness (North 1976:14).

What Theonomism adds to eschatology, is that the Church, through the working of the Holy Spirit, must participate in the golden age, by bringing about the Kingdom of God by implementing and applying the Old Testament judicial laws. Kline (1977) clearly explains this:

The brand of postmillennialism adopted by the Chalcedon (Theonomist) writers includes something more. They do appeal to the prophecies that portray the messianic kingdom after the model of the visible Israelite theocratic kingdom and they interpret this prophetic picture as having fulfilment - visible, earthly fulfilment - during the millennium (which they understand as being coextensive with the pre-consummation history of the New Testament church rather than a special period at the close of that church age, as many other postmillennialists view it). Thus, Bahnsen maintains that the theocratic reality which fulfils those prophecies already exists and will come to increasing visibility in preconsummation history. Within the millennium, a universal theocracy (or Christocracy) will prevail on earth with all nations and kings serving and blessing Jesus Christ, the Lamb on David's throne. (p. 630)

Although Theonomists have widely differing views on how and to whom the judicial laws should be applied on earth, the Church plays a key role in the implementation or initiation of the application of the judicial laws (Ice 2017:66). According to Theonomism, the fullness of time, that is the completion of the Millennium, will only take place after a worldwide Christian Theocracy or Christocracy has been established (North 1988:392-393). All Theonomists are therefore labelled as Postmillennialists, because the Kingdom of God must be established on earth, through the restructuring of society into one that is ruled by a Christocracy.

\section{Critical evaluation of Theonomist eschatology}

The uniqueness of Theonomism's eschatology lies in its specific understanding of the Kingdom of God, established on earth through the implementation and application of the Old Testament judicial laws by the Church, or various forms of government. North (1987) says:

The missing element was biblical law, once the details of the theonomist position began to take shape, Christian Reconstructionism became a full-fledged system Biblical law establishes the basis of a positive alternative. (p. 1)

North is referring to the missing element which Rushdoony (1973) added to the work of Van Til. This missing element was the law, with a specific emphasis on the Old Testament judicial laws. North (1987:2) criticises Van Til for his 'Amillennial pessimism', and for the fact that Van Til viewed the Reconstruction movement as a fringe movement and not as cutting edge. ${ }^{3}$

This core element of Theonomistic eschatology lies in the Theonomistic hermeneutical principle of the continuity between the Old and New Testament covenant. This continuity of the covenant contrasts with Dispensationalists' focus on the discontinuity of the covenant between the Old and New Testaments. Kline (1977) explains:

To put the matter in a comparative perspective, this theory of Theonomic politics stands at the opposite end of the spectrum from Dispensationalism. The latter represents an extreme failure to do justice to the continuity between the Old and New covenants. Chalcedon's error, no less extreme, is a failure to do justice to the discontinuity between the Old and New covenants. (p. 619)

3.For more details on this debate, refer to lce (1988) 
According to Kloosterman (1994:3), Theonomism and Dispensationalism are similar in their hermeneutics in that they do not do justice to the historical, progressive character of biblical revelation.

The hermeneutical error of Theonomism is entrenched in the distinction it makes between the royal and priestly elements of the Kingdom of God. The Israelite kingship along with the priesthood forms part of the theocratic prototype of God's redemptive work, which points to the redemptive work of Jesus Christ. This thought is part of the hermeneutical error that the Chalcedon movement and specifically Bahnsen make. The whole kingdom of Israel serves as typology - not just the priestly or the kingly part (Kline 1977:629). Bahnsen (2002:427) acknowledges, for example that the ceremonial laws were fulfilled in the work of Jesus Christ, to the extent that they no longer need to be kept today, and that they served as a prototype of Christ's work. However, Bahnsen exempts the judicial laws from the prototypical Kingdom of God, because he believes that the judicial laws must still be applied by the Church, monarchs or governments today. Bahnsen (2002) says:

That means that the civil magistrate is supposed to execute capital punishment in all cases for which it is prescribed by Moses, and thus not only for offenses such as incorrigibility in children and homosexuality, but for offenses like blasphemy, apostasy, idolatry, witchcraft, Sabbath-breaking, advocacy of worship of other gods than Yahweh, etc. (p. 439)

In doing so, Bahnsen exempts the kingly government of Israel from the prototypical Kingdom that points to Jesus Christ.

Theonomistic hermeneutics causes its eschatology to have no choice but to move the Kingdom of God to a future expectation, that will only come about in the golden age through the establishment of a Christocracy (Gaffin 1990:201). The establishment of this Christocracy shifts the focus of the Church to the reconstruction of society. The agenda, task and focus of congregations should, therefore, according to Theonomistic eschatology, shift to an administrative plan for how the Kingdom of God is to be built on earth, according to Old Testament laws (Beed \& Beed 2017:18). Kloosterman (1994) adds:

Probably contrary to the desires and intentions of modern theonomy's best exponents, the movement as a whole has spawned a kind of evangelical activism within the church that is in danger of substituting a Christianized society for the church's primary mission of preaching unto repentance and conversion. (p. 17)

This shift in focus for congregations has enormous implications for how each congregation views their calling.

The Theonomistic eschatology causes a focus on calling, where members must actively participate in the establishment of the Christocracy on earth. By its very nature, this calling focuses on and requires a great deal of commitment to the development of God's kingdom as an obligation. This view on calling is heavy, and success in the calling is accomplished by restructuring all societal contexts in which the members are involved (Ray 2016:13-15). Failure in one's calling is therefore catastrophic. There is also no uniformity among the leaders of Theonomism on how this calling is carried out, and exactly how the Christocracy should be built. The church calling to establish the Christocracy, brings tremendous tension in congregations. This atmosphere created in congregations, leads to great division.

To provide a critical evaluation of the Theonomistic form of Postmillennialist eschatology, another form of Postmillennialism must be considered, namely Amillennialism. Amillennialism is a form of Postmillennialism, because it also expects the return of Christ after (post) the symbolic Millennium. The characteristic distinction between Amillennialism and Theonomistic Postmillennialism is the view on the golden age. Amillennialism does not believe that the Church will experience any golden age on earth in present times. Wherever the church flourishes, according to Amillennialism, there will always be great opposition. The Kingdom of God is only visible in the Church through believers who are converted. The Kingdom of God is not established by the application of judicial laws by social institutions, or forms of government. According to Amillenniastic eschatology, the Kingdom of God is something that has already come, and not something that still needs to come. However, the fullness and final establishment of the Kingdom of God is something that would only instituted after the return of Christ, by the union of heaven and earth (Venema 2000:233).

Criticism of the Amillennialist eschatology is that it easily leads to passivity, which does not promote missionary work; or that it adopts an anti-community or institutional attitude (Allen 2018:17). This critique is something that Amillennialists should take to heart. The Reformation of the 16th century was characterised by its restructuring of societal relations, such as the Church, family, school and university. However, the restructuring of the societal bonds was not to bring about a Christocracy on earth, but to bring members and communities under the teaching of the Word of God. Many of the school and universities established during the Reformation are currently no longer Christian; on the contrary, they are completely secular. This does not mean that God's Kingdom has failed. The agenda, focus and task of the Church is the proclamation of the gospel, and not the establishment of a Christocracy.

Theonomist Postmillennialism views the church as a visible, geographical, political institution that rules on earth before the return of Christ. Kline (1977) explains it as follows:

Bahnsen's position is that the Old Testament prophecies of visible prosperity for the kingdom are being fulfilled in the visible prosperity of Christ's established kingdom on earth, in the present visible church on earth undergoing development in relation to the nations of the world. (p. 627)

Amillennialism also views the Church as a geographical political institution, but it differs from Theonomist Postmillennialism in the sense that they do not regard the Church as a visible geographical political institution before the return of Jesus Christ, but that these prophecies of the visible state of the 
church rather indicates something that will come about after the Second Coming, in its eternally glorified form.

Theonomist Postmillennialism, as Bahnsen (2002:428) puts it, emphasises material progress and the growth in power of Christ's Kingdom on earth. In this, the nations that do not want to bow under the authority of the Christocracy, are forced to bow. Kline points out that millennial theories such as Theonomist Postmillennialism and Dispensationalism, which await the visible messianic kingdom on earth before the return of Jesus Christ, will be forced to deny or annihilate the sphere of the state in their social doctrine, because there will be no room for any other form of government on earth, except for the messianic kingdom.

From this one can deduce that Theonomy advocates a type of Christianised state, an ideal state that acts on behalf of the Saviour on earth. Bahnsen (2002:426), however, is unable to identify his millennial Christocracy with the state. It is for this reason that the Theonomists also logically come to the rejection of the state as sovereign sphere. In this, Theonomists in Reformed Churches find the dilemma regarding the confession of the Belgic Confession article 36, because they do not want to acknowledge the role of the state. As Kline (1977) notes:

Indeed, it is this model of the Israelite kingship that is used when Old Testament prophecies depict the theocratic kingship of the future age, the Christocratic kingship which does operate in the name of the Redeemer-God, as Bahnsen recognizes and for that very reason, finds he cannot identify it with the civil magistracy. In this recognition of the truth, that the civil magistrate does not function in the name of the Redeemer, Bahnsen lets in by way of the back door, the fact that there is after all a decisive difference between the Israelite theocratic kingship and the civil magistrate. (p. 630)

The eschatological view of Theonomist Postmillennialism changes the nature of missionary work. They believe that it is now the Church's role to establish the Kingdom of God on earth, by implementing the Kingdom's judicial laws. This causes their attitude towards missionary work to change to an aggressive Christocracy, where the Church forces the nations to live under the rule of the Christocracy. 'For God's commission to the civil magistrate, as understood in theonomic politics, stands in unmanageable tension with God's commission to the church to evangelise the nations' (Kline 1977:629). From this, the great danger of Theonomistic Postmillennialism becomes visible, because according to Gaffin (1990:16) it undermines the core task of the Church, namely to proclaim the gospel to the nations, while being 'aliens and strangers on earth' (Heb 11:13). Theonomistic Postmillennialism tries to take over the work of the Holy Spirit by forcing unbelievers to live under a Christocracy (Gaffin 1990:17). It is precisely from this eschatological perspective that Reformed Church councils experience a lack of love among some Theonomists.

This eschatological view of Theonomism reduces the eschatological expectation of the Church. It denies that Christ, through his Spirit, has been building his Kingdom for the last 2000 years. There can be joy over one sinner who is converted, but according to Theonomist eschatology, this is not enough, because they are waiting for the visible Kingdom on earth. The idea of what Kline (1977:630) calls a 'cult-like fanaticism, censoriously disruptive of the Reformed community', easily develops from Theonomistic eschatology. The reason for this 'cult-like fanaticism' is their eschatological view of the Church, which must establish the visible Kingdom of God on earth. When the Church is not part of this Christocracy, it is not fulfilling its calling. Kline (1977) postulates:

Exposed here in the content and mood of Chalcedon's eschatological teaching, is something at once deep and characteristic in Chalcedon, and yet terribly alien to the gospel of Christ, alien to the spirit of the church's present evangelistic mission in the world, alien to the eschatological patience of biblical faith and hope and love. (p. 630)

Gaffin (1990:201) views Theonomist eschatology as a 'deeschatoligizing' of the Church. Thus, Theonomism is destroying the eschatology of the Church in their view that the Church must bring about the Kingdom of God on earth in this Millennium, through the application of the judicial laws. According to North (1976:13), common grace will increase in the ages to come, developing into a golden age. The problem with this eschatological view is that the emphasis on this golden age, which is wholly future-oriented, leaves an impression on the present Church that we are not now in the golden age. Furthermore, the Church has not been the victorious Church in the past. With such eschatological expectation of the golden age, the current state of the Church is easily condemned, and the Church is scorned for its passivity and lack of involvement in changing the structures of society (Allen 2018:32).

Theonomistic eschatology causes an underestimation of the New Testament eschatology. By emphasising the Kingdom of God in the future, and the Church that is to bring the Kingdom of God on earth, the coming of God's Kingdom as a present reality is undermined. A focus on the eschatological expectation that has yet to come to earth, causes the Church to do everything to bring the Kingdom of God to earth one day in the golden age. Excitement about Christ who reigns and calls sinners to repentance now through His Word and Spirit is lost. Theonomistic eschatology causes the Church to fall into a de-eschatology.

Furthermore, according to Venema (2000:344), there is only two passages in the New Testament alluding to a golden age, namely 1 Corinthians 15:22-26 and Revelation 20:1-6. 'Upon careful study, however, neither of these passages teaches such a distinction' (Venema 2000:344). According to Venema (2000:234) New Testament eschatology teaches that the eschatological kingship of Jesus Christ already began at his first coming, which culminated in his resurrection and ascension. Even at Christ's transfiguration, God put all things under his feet. The whole time between Jesus' first coming and return, the time in which we presently live, is called the 'golden age', unlike the 
Theonomistic eschatology, which regards the golden age as something yet to come. To describe the 'golden age' as something future-oriented, something that will only happen when the messianic kingdom is established on earth, is a denial of the eschatological quality that the church is currently experiencing. The effect of Theonomistic eschatology, Gaffin (1990) says, is that:

[T] he present exercise of Christ's (eschatological) kingship, as presented in the New Testament, is decisively diminished. His kingship, in effect, is held in abeyance; rather than being a present actuality, it is largely a matter of potential, poised for its future, 'golden' exercise. (p. 202)

The eschatological expectation of the Church determines the focus of the Church's task on earth. According to Amillennialism, any opposition experienced by the Church should not discourage the Church, but rather lead it to perseverance in the proclamation of the gospel. The reality is that the Church has experienced opposition, from Christ's ascension through the ages, and will continue to encounter resistance in the future. The church's focus on obeying Christ's command to preach the gospel to all nations should not be taken over by building an earthly kingdom. Christ is building his Kingdom through the ages. Abraham, Lazarus, and all the other faith testimonies are already part of this kingdom. The Kingdom of Christ can be exceedingly small on earth at times, but this does not affect the greatness of God's Kingdom in heaven. Therefore, the angels sing in joy over one sinner who is converted. The Church are strangers on this earth. The Church does not seek fixed structures and earthly foundations in the implementation of judicial laws. The Church clings in faith to the heavenly city, which has solid foundations, and of which God is the builder. Despite the opposition the Church is experiencing here on earth, the Church is not taking its eyes off Christ, who is already victorious.

\section{Conclusion}

According to Carter (2021):

It cannot be denied that theonomists are characterized by a sincere desire to honour Christ as Lord. Neither can it be denied that theonomists, as a group, tend to be very well prepared! But it can be argued, and it is often argued, that they have not yet learned to make their defense with gentleness and respect. And until they do, they will not likely serve the corrective function within evangelicalism, that they likely would otherwise. While I am not, and almost certainly never will be, a theonomist in terms of the total system of beliefs, I do believe that a wider exposure to their passion for the Old Testament, and their commitment to evangelism and Christian education, could serve as a muchneeded tonic against the increasing corruption and confusion of the evangelical movement. $(p, 2)$

From Carter's quote, it seems that Theonomism has made an important contribution to Christian thinking in different areas, and interaction with these Theonomistic ideas should be carefully considered. The focus of this article, however, was to show that the Theonomistic eschatological view leads congregations' focus to shift from proclaiming the gospel, to seeking to restructure the institutions of political societies to form a Christocracy. Although the extreme form of Theonomism has only affected a small number of Reformed members in South Africa, it seems that Theonomist Postmillennialism has a greater underlying influence in the Reformed Church in South Africa. As Ingersoll (2015:6) points out, 'the Reconstructionism has effects that are subtle, implicit, and hidden'. In addition to numerous pastoral issues arising from Theonomy, which are consistent with Hall's (2015:10) estimation, one of the greatest influences of Theonomy lies in its influence on the focus and task of the church.

The Church's eschatology has a significant effect on its identity and its understanding of its role and task in the present age. Gaffin (1990:210) explains that the Church does not understand its identity, role, and task in this creation if it does not fully embrace the current eschatological reality of Christ's rule. Vos (1979) puts it as follows:

This is the eschatology taught in the New Testament - a realised-eschatological and therefore decidedly optimistic Amillennialism, optimistic about the victory - present (and past) no less than future - being realised in and through the church. (p. 34)

Misunderstanding eschatology affects the Church's identity and focus in this world. The Postmillennialist optimism of the Kingdom of God on earth, to the extent that the Church will receive almost no opposition during the 'golden age', leads to a wrong perspective on the Church's task in the world.

According to Jesus, the church will not have drained the shared cup of his suffering, until He returns. The church cannot afford to evade that point. It does so at the risk of jeopardising its own identity (Gaffin 1990:210).

\section{Acknowledgements Competing interests}

The author declares that he has no financial or personal relationships that may have inappropriately influenced him in writing this article.

\section{Author's contributions}

M.D. is the sole author of this research article.

\section{Ethical considerations}

This article followed all ethical standards for research without direct contact with human or animal subjects.

\section{Funding information}

This research received no specific grant from any funding agency in the public, commercial, or not-for-profit sectors.

\section{Data availability}

The authors confirm that the data supporting the findings of this study are available within the article. 


\section{Disclaimer}

The views and opinions expressed in this article are those of the author and do not necessarily reflect the official policy of position of any affiliate agency of the author.

\section{References}

Allen, M., 2018, Grounded in heaven: Recentering Christian hope and life on God, Eerdmans, Grand Rapids, MI.

Bahnsen, G.L., 1991, No other standard: Theonomy and its critics, Inst for Christian Economics, Tyler, TX.

Bahnsen, G.L., 2002, Theonomy in Christian ethics, 3rd edn., Covenant Media Press, Nacogdoches, TX.

Beale, G.K., 2011, A New Testament biblical theology: The unfolding of the Old Testament in the New, Baker Books, Grand Rapids, Ml.

Beed, C. \& Beed, C., 2017, 'Biblical interpretation of Gary North's theonomy', Journa of Biblical Integration in Business 20(2), 10-19.

Burack, F., 2017, 'Book Review: Ingersoll, J., 2015. Building God's kingdom: Inside the world of Christian reconstruction', Oxford University Press, USA, Critical Research world of Christian reconstruction', Oxford University Press, USA, Critic
on Religion 6(1), 1-4. https://doi.org/10.1177/2050303217732136

Carter, P., 2021, Why / am not a Theonomist, Semper Reformanda, viewed 13 June 2021 from https://semperreformanda.ca/2021/02/16/why-i-am-not-a-theonomist/.

Frame, J., 1976, 'The institutes of biblical law: A review article', Westminster Theological Journal 38(2), 195-217.

Gaffin, R.B., 1990, 'Theonomy and eschatology: Reflections on postmillennialism', in W.S. Barker \& W.R. Godfrey (eds.), Theonomy, A reformed critique, pp. 197-224, Zondervan, Grand Rapids, MI.

Gaffin, R.B., 2006, 'By faith, not by sight': Paul and the order of salvation, Paternoster Gentry, K.L., 1993, God's law in the modern world: The continuing relevance of Old Testament law, P\&R, Phillipsburg, NJ.

Hall, J.D., 2015, Embers of a dying fire: My thoughts on the great theonomy debate, Audio version narrated by Landan Chapmen.
Ice, T.D., 1988, An evaluation of Theonomic Neopostmillennialism, Faculty Publications \& Presentations, Austin, TX

Ice, T.D., 2017, 'Christian reconstructionism', in T.J. Demy \& P.R. Shockley (eds.) Evangelical America: An encyclopedia of contemporary American religious culture, ABC-CLIO, Santa Barbara, CA.

Ingersoll, J., 2015, Building God's kingdom: Inside the world of Christian reconstruction Oxford University Press, New York, NY.

Kline, M.A., 1977, 'Review of Greg L. Bahnsen: Theonomy in Christian ethics', The Craig Press xvii, 619-630.

Kloosterman, N.D., 1994, 'Theonomy and Christian reconstruction', in International Theological Congress at Noordwijkerhout, The Netherlands, June 2-24, viewed 21 July 2021, from https://www.academia.edu/362582/Theonomy_and_Christian_ Reconstruction.

McCrorie, B., 2006, Theonomy and the regulative principle of worship, viewed 12 June 2021 , from https://bowingdown.wordpress.com/2006/10/17/theonomy-andthe-regulative-principle-of-worship/.

McVicar, M.J., 2015, Christian reconstruction: R.J. Rushdoony and American Religious Conservatism, University of North Carolina, Chapel Hill, NC.

North, G., 1976, 'Common grace, eschatology, and biblical law', Journal of Christian Reconstruction 3, Winter 1976, 77, 13-47.

North, G., 1987, Dominion and common grace: The biblical basis of progress, Dominion Press, Fort Worth.

North, G., 1988, Unholy spirits: Occultism and New Age humanism, Dominion Press, Waterbury Center, Vermont, VT.

North, G., 1991, Christian reconstruction: What it is, what it isn't, pp. 80-82, Inst for Christian Economics.

Pipa, J.A., 2020, Worship reader, Greenville Presbyterian Theological Seminary, Greenville.

Ray, M., 2016, Theonomy: Whose in charge - Its God's church, iUniverse, Bloomington, IN Rushdoony, R.J., 1973, The institutes of biblical law, The Craig Press, Nutley, NJ.

Venema, C.P., 2000, The promise of the future, The Banner of Truth Trust, Edinburgh. Vos, G., 1979, Pauline eschatology, P\&R, Phillipsburg, NJ.

Wenham, G., 2006, 'Law in the Old Testament', in J.W. Rogerson \& J.M. Lieu (eds.), The Oxford handbook of biblical studies, pp. 351-362, Oxford University Press, Oxford. 